\title{
PRIVATE EQUITY MARKET OF THE VISEGRAD GROUP
}

\author{
Jozsef Popp ${ }^{1, a, *}$, Judit Olah", ${ }^{2, b}$,Veronika Machova ${ }^{3, c}$ and Agnieszka Jachowicz ${ }^{4, d}$ \\ ${ }^{1}$ Debreceni Egyetem, Gazdaságtudományi Kar, Ágazati Gazdaságtan és Módszertani Intézet, \\ Boszorményi út. 138, 4032 Debrecen, Hungary \\ ${ }^{2}$ Debreceni Egyetem, Gazdaságtudományi Kar, Alkalmazott Informatika és Logisztika Intézet, \\ Boszorményi út. 138, 4032 Debrecen, Hungary \\ ${ }^{3}$ University of Economics Prague, Faculty of Business Administration, W. Churchill 4, 13067 Prague, \\ Czech Republic \\ ${ }^{4}$ University of Dabrowa Gornicza, Department of International Enterprise and Finance, Str. Cieplaka \\ 1c, 41-300 Dabrowa Górnicza, Poland \\ apopp.joszef@econ.unideb.hu, bolah.judit@econ.unideb.hu, cmacv11@vse.cz, dajachowi@pg.edu.pl \\ *Corresponding author
}

Cite as: Popp, J., Olah, J., Machova, V., Jachowicz, A. (2018). Private equity market of the Visegrad group, Ekonomicko-manazerske spektrum, 12(1), 1-15.

Available at: dx.doi.org/10.26552/ems.2018.1.1-15

\begin{abstract}
Private equity is medium to long-term finance provided in return for an equity stake in potentially high growth unquoted companies. Private equity is capital that is not listed on a public exchange. Private equity is composed of funds and investors that directly invest in private companies, or that engage in buyouts of public companies, resulting in the delisting of public equity. Institutional and retail investors provide the capital for private equity, and the capital can be utilized to fund new technology, make acquisitions, expand working capital, and to bolster and solidify a balance sheet. Private equity investment comes primarily from institutional investors and accredited investors, who can dedicate substantial sums of money for extended time periods. In most cases, considerably long holding periods are often required for private equity investments in order to ensure a turnaround for distressed companies or to enable liquidity events such as an initial public offering or a sale to a public company. Thus, the aim of the paper is to compare the usage of the private equity by small and medium-sized enterprises in V4 countries with a focus on the accessibility and preferences. The paper is divided into several parts. The first part is devoted to the literature review of theoretical resources of the private equity term, its distribution and its usage in the region. The second part is dedicated to theoretical definition of private equity issues and concepts which are connected with private equity investments. The paper is focused on the analytical research of issue. A comparative analysis is used to compare the use of the private equity in selected countries. The correlation and regression analyses, which determine factors of influence on country attractiveness for private equity investors, were realized.
\end{abstract}

Keywords: private equity; venture capital; Visegrad group; regression.

JEL Classification: D25, G24, O52

\section{Introduction}

Private equity (PE) may be defined as shares representing ownership of or an interest in an entity - that is not publicly listed or traded. A source of investment capital, private equity 
actually derives from high net worth individuals and firms that purchase shares of private companies or acquire control of public companies with plans to take them private, eventually become delisting them from public stock exchanges. Most of the private equity industry is made up of large institutional investors, such as pension funds, and large private equity firms funded by a group of accredited investors.

In continental Europe, the term private equity is synonymous with the term venture capital. Both terms stand for a medium or a long-term financing provided in order to gain a part of equity of a company, shares of which are not publicly traded and that have a potential to generate wealth in the future. The investment period is usually between 4 to 7 years. In the USA, private equity has always been divided in two subgroups; (i) venture capital (used for financing of small companies in the initial phase of growth and (ii) buyout and buy-in transactions (taking over control of companies in a later stage of development). As the majority of documents published by European Private Equity \& Venture Capital Association (EVCA) inclines to the American comprehension of the term private equity, we shall do the same or mention if not. Private equity investments are quite risky; therefore, financial investors need to be well organized to control the risk. They establish private equity funds. PE funds are special purpose companies intended to collect sources from investors to invest them in a target company or in other private equity funds.

Private equity funds are generally structured as limited partnership, which is controlled by a private equity firm that acts as the general partner. The limited partnership is often called fund and the general partners are designated as the management company. The management company cooperates with the fund on the contractual basis and is in charge of searching investment opportunities, carries out the evaluation of profitability, realizes the projects, monitors them and then resells the purchased companies. Even though, the management company that stands behind the selecting process, it is upon the fund to decide in the end. Therefore, each fund has an investor committee composed of investors and often also of representatives of the management company, which pronounces the final decision about a project. The reason for choosing the limited partnership form stems from the fact that the limited partnership form is usually defined quite vaguely in the national legislation, which enables the founder to make particular specification on behalf of different types of investors in the partnership agreement, according to Dvorak \& Prochazka (1998).

Most PE funds are founded for a limited period of time, usually 8 or 10 years, when they typically make about 20 separate investments with usually no single investment exceeding $10 \%$ of the total commitments. At the end of their life, they are obliged to liquidate all the investments. Existence of the fund is divided into three overlapping stages:

1. Investment stage - this stage usually lasts for about three years and is dedicated to capital collection, to the search for target companies and finally to the investment itself. Concerning the collection of capital from investors, a PE fund prefers several subsequent drawdowns to collecting the whole amount at once. This requires the investor to hold sufficiently liquid assets to be able to satisfy the call immediately as it occurs, only two or three weeks in advance. If he is not able to comply with the requirement, he is exposed to a penalty. In the EVCA terminology, this technique is called the "just-in-time drawdowns". It is used to minimize the amount of cash that remains in the fund without being invested. The more uninvested cash the fund holds, the lower the internal rate of return, which measures its performance; therefore, the less profitable the fund appears.

2. Maturity stage - maturity stage is in the name of growth and expansion of the invested capital, monitoring the cash flows, management of the company and control of the risk and 
strategy. This stage usually lasts for 4-7 years, during which it becomes evident, which projects were good investments and which were the loss-making one.

3. Exit stage - this is the final stage which shows the real profits for investors as well as for the management company of the fund. There is no optimal duration of the third stage as the best moment to resell a company is strictly individual. Every management company usually manages a few funds at some moment, each of them in a different stage. Therefore, whenever one fund reaches the "harvest period", the profits are distributed among investors and the fund is closed, there is another fund that is entering the exit stage and the management company usually establishes a new fund soon after.

\subsection{Literature Review}

Various academic studies and authors define private capital (PE) differently depending on the nature of the economy. In general, private equity is a type of non-listed stock. It is a source of investment capital from institutions with amount of capital to invest and acquire ownership in a company, argued by Stowell (2018).

Private equity includes a risky, long-term and profitable commitment and provides a strong financial base and expertise to the company. Isaksson et al. (2004) defined private capital as a specific form of corporate finance that is globally one of the largest non-bank sources of medium to long-term capital. Leeds (2015) defined private capital as a financing source of early and late stages of private companies from third party investors looking for a high return based on the corporate risk profile and the short-term illiquidity of these investments. Burdel (2009) explains private capital as a shelter against the short-term vision and volatility of stock markets and provides a stable platform for rapid, highly concentrated growth at key points in the corporate development. He argues that private capital is less liquid than publicly traded shares and is therefore thought to be a long-term investment. Mason \& Harisson (1999), in a broader sense, understand private capital as investment by institutions, companies, and wealthy individuals in non-listed companies that have high growth potential and can become significant players in the international market.

Private capital is a form of investment. It is included in an alternative type of investment in a security. In the widest sense, investment means giving up a certain value in order to obtain a certain future value, argued by Sharp \& Alexander (1994). Similarly, Kaplan \& Strömberg (2009) went on a similar path, claiming that the investment is understood to be the acquisition of such an asset, which in the future will bring some economic benefit to its owner or will be evaluated in the future. In private equity, this asset is a share in a particular company. Investor's entry into the funded company is therefore not only a financial injection but also a partnership. Link et al. (2012), and Bygrave \& Timmons (1992) broaden this definition in their studies. They dealt with the influence of an investor in the funded company and concluded that the PE investor activity generally leads to above-average performance of the funded company and also leads to a higher internationalization rate.

Gervasoni \& Sattin (2006) claim that private equity can finance anything with investment potential. Investments can be given for the development of new products, new technologies, or investment can be used to expand production or consolidate the financial position of an enterprise. However, the purpose of redemption of a share in an enterprise may also be to resolve a problem associated with the arrangement of ownership of an enterprise or its overall reorganization. EVCA (2007) argues that private equity is the provision of equity for mediumor long-term horizon, provided by financial investors to companies that are not traded on a public stock exchange and have high growth potential. The goal of private equity is to help companies achieve their growth ambitions by providing them finance, strategic advice and 
information at very important stages of their development. Private equity does not only cover the financing required for the business operation but it also includes financing at later stages of the life cycle. In its definitions, there are three main notions to be distinguished venture capital, private equity and business angels. Venture capital is a type of private equity that focuses on emerging companies, start-up. The term private equity refers to the form of the capital investment in private companies that are not traded on the stock exchange. Venture capital is therefore a subset of private equity. Capital of business angels is a specific form of private equity of investors who are not formally associated and provide their capital individually, according to Nyvltova \& Reznakova (2007). Veber (2008) searched the use of private equity in various countries. The principle is that the private equity fund enters into the company in the form of a capital increase. In this way, the company will acquire the necessary resources, and after a few years, the equity capital of the private equity fund will be redeemed and the investments will be returned to the fund. The main objective of the private equity fund is to invest, evaluate, sell, and re-invest in other opportunities. The fact that PE funds play an important as financial mediator on the private equity market was declared in the study of Stowell (2018) and Diaconu (2012).

Companies funded by private equity may achieve many benefits. Kortum \& Lerner (2000) argued that private equity has a strong positive impact on the rise of ideas and inventions. Sharing technologies in the economy in return increases productivity and company profits. Fryges \& Wright (2014) showed that German companies with the capital from private investors invested more in research and development and were more creative and willing to share technologies than other companies were. Achleitner \& Klöckner (2005) concluded that the average employment rate is higher in companies funded by venture capital.

Venture capital has attracted more attention in practice and literature by delivering a positive impact on companies with high growth potential linked to innovation by producing new technologies, increasing profits, industrial development and increasing employment. National governments have recognized the importance of funds and investing in high-risk activities and admitted that the corporate access to fund resources can be crucial for their research, profits and visibility. The low rate of capital may be problematic when considering their important role in innovation increasing.

\section{Methodology and Aims of the research}

The main aim of the study is to compare the use of private equity as a source of investment of small and medium-sized enterprises in Visegrad group and to provide a view of the development and usage of private equity.

In the analytical section, the situation of the private equity use in the V4 countries is depicted and the focus is on the factors that affect the way of private equity obtaining. Firstly, the PE situation in Central and Eastern Europe is described in the period of last four years. The analyses of investments in small and medium sized companies in the V4 counties is conducted to determine the source of capital investors provide considering the corporate life cycle. Secondly, the country attractiveness for a PE investor is measured, using the global attractiveness index of countries in the area of PE capital. The author analyses the factors and sub-factors of the index and the score achieved, and the results of the V4 countries in 2017 are portrayed. Finally, a method of correlation analysis is used to determine which factor most affects the resulting score achieved in the attractiveness index. By regression analysis, we form a regression equation to estimate the value for the next period. We compare the given value with the best countries and values as well as with the global competitiveness index of the countries. 
All the data are presented for SMEs, although some of the data obtained may contain information about large enterprises. This data does not distort the formulations and results because in all V4 countries the share of small and medium-sized enterprises is at least $99 \%$ (Eurostat), which means that the variance is negligible.

\section{Results}

The countries of the Visegrad group belong to Central and Eastern Europe (CEE), having similar historical (part of the Eastern Bloc), geographic or economic backgrounds. For the past eight years, the CEE has achieved stable numbers in the volume of PE resources to finance private equity of SMEs, however, it is far from reaching the level they achieved in the years before the financial crisis (2006-2008).

Figure 1: Volume of investments in CEE region, 2003-2016

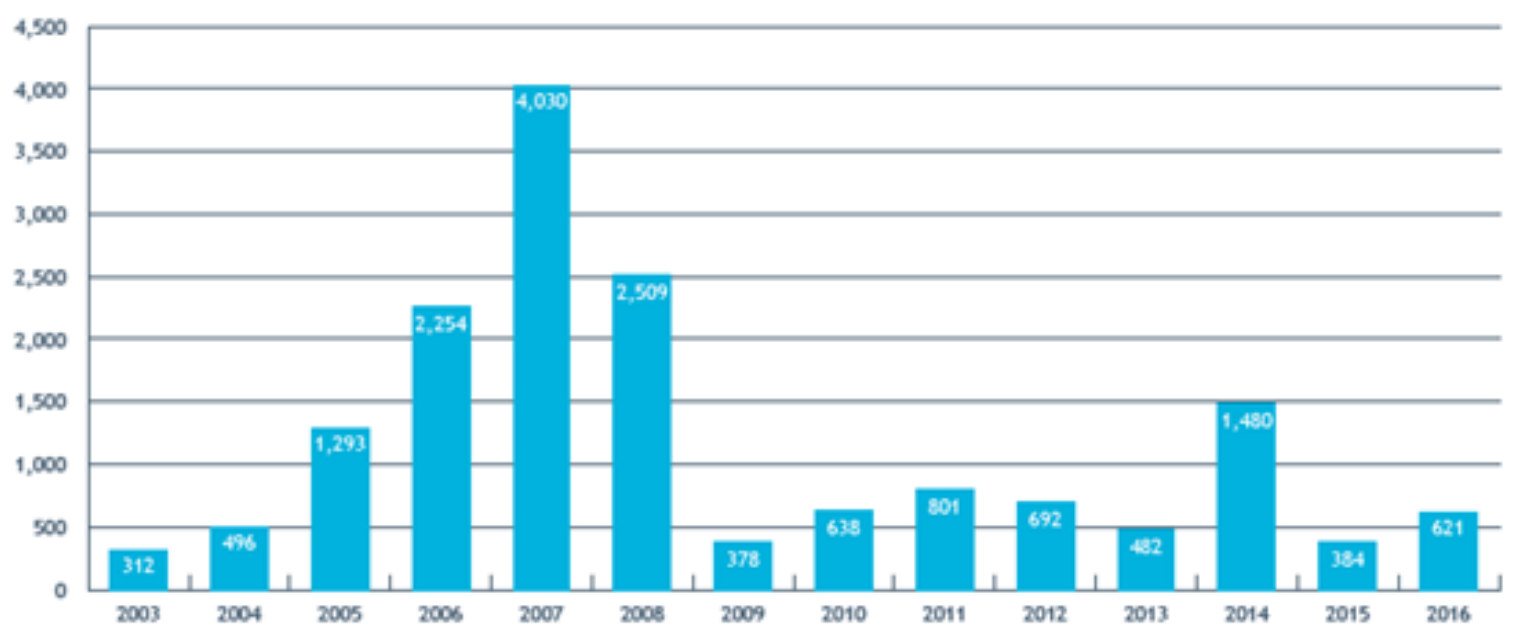

Source: EVCA

As it may be seen, the greatest volume of the PE sources were gained in 2007. For the past eight years, only the year 2014 deflects from the steady trend, when the positive leap came, and the CEE countries raised funding of 1.48 billion euros, which on the other hand represents only $36.7 \%$ compared to 2007 . The increase in the year 2014 was even more noticeable due to the decrease in the total volume of resources across Europe that year. This can be explained by high GDP growth, low inflation and decrease in unemployment in many CEE countries, creating an attractive space for PE investors. When comparing the last two years, we observe that in 2016 CEE countries increased their PE resources by $€ 237$ million. This change represents a $61.7 \%$ increase compared to previous year 2015 and sets positive expectations in the future years.

The boom in the volume of PE investments provided by SMEs in CEE countries was in 2006, the volume of investments grew by 2008 when it reached its maximum. This increase was due to the considerable potential of this area, which attracted institutional investors and PE funds. In the following year, there has been a slight decline, but in 2010 the world economic and financial crisis influenced alsi the situation on the CEE market resulting in a huge fall in investment and stagnation continued until 2013, when the crisis was finally overcome and the investors` confidence was regained. In 2013, the CEE invested 847 million euros, with the share of V4 countries accounting for $75.4 \%$ of total investments. In 2014, the share of V4 investments fell to 55.4\% and rose to at least 60\% in 2015 and 2016 (EVCA, 2016). These shares show that in the CEE region, the economic power in the PE investment sector is a majority. Looking at 
the results of specific V4 countries in more detail, we find that one country significantly outperforms others (Figure 2).

Figure 2: PE investments in mil. $€$ in V4 countries

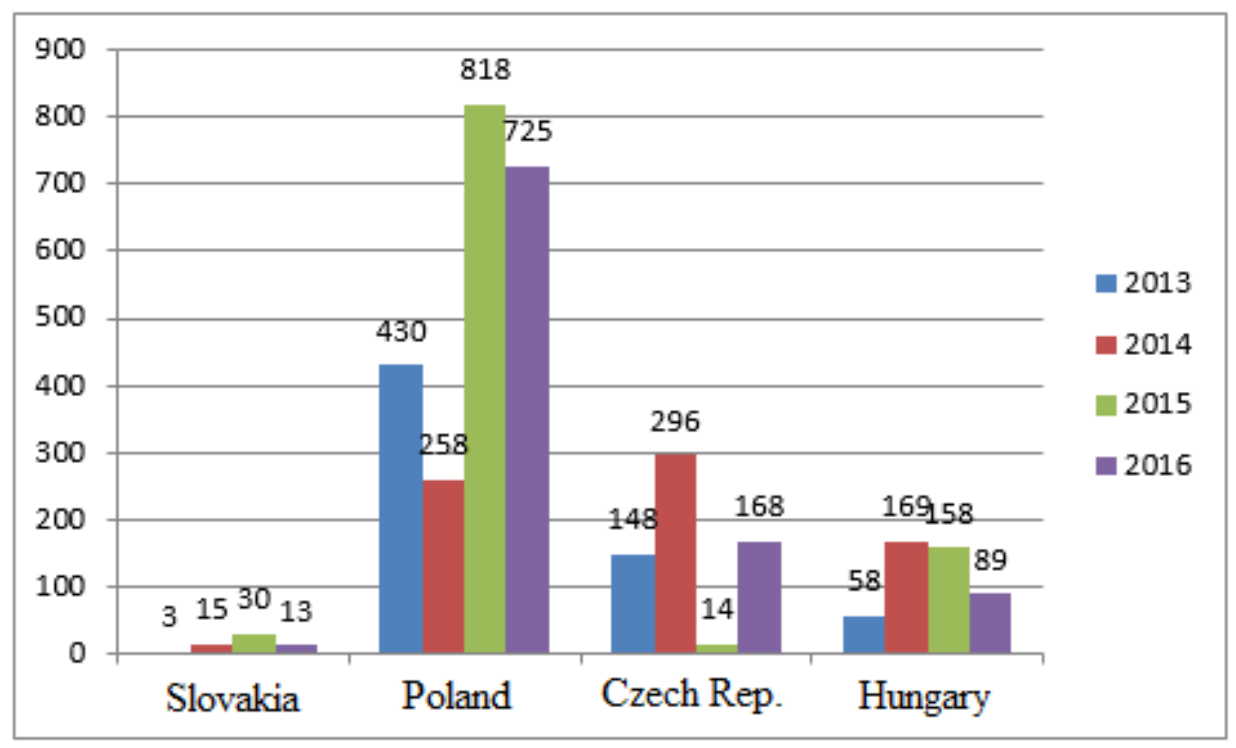

Source: EVCA

Figure 2 demonstrates that Slovakia is the country with lowest level of PE investments. However, positive is the fact that the popularity of the private equity in Slovakia has arisen recently, which presents its potential for new investors (EVCA, 2016). According to the available data, we can assume that in 2015 an average of EUR 1.36 mil. was invested in one enterprise, whereas in 2016 it was on average less than 500 thousand euros. The decline in investment in SMEs resulted in increased volume of investment in seed and start-up SMEs, which require a lower initial capital ratio and a reduction in the number of managerial buy-outs. Among the countries, but especially from the perspective of the time horizon, there are differences in the level of investment per enterprise. These differences have arisen with the different types of PE investment. Therefore, in Tables 1 and 2, it is shown which types of investments the country has provided for 2015 and 2016.

Table 1: Volume of investments in thousands $€$ considering the type of investment (2015)

\begin{tabular}{lllll}
\hline Type of investment capital & Slovakia & Poland & Czech Republic & Hungary \\
\hline Seed financing & 1,740 & 4,691 & 300 & 3,021 \\
Start-up financing & 4,619 & 17,761 & 1,300 & 18,729 \\
First stage financing & 2,750 & 6,421 & 70 & 3,068 \\
Expansion financing & 7,000 & 79,385 & 8,750 & 38,482 \\
Rescue capital & 0 & 0 & 0 & 0 \\
Debt replacement capital & 0 & 22,708 & 0 & 0 \\
Managerial buy-outs & 13,400 & 686,784 & 3407 & 95,000 \\
TOTAL & 29,509 & 817,750 & 13,827 & 158,300 \\
\hline
\end{tabular}

Source: $E \overline{V C A}$

Table 2: Volume of investments in thousands $€$ considering the type of investment (2016)

\begin{tabular}{lllll}
\hline Type of investment capital & Slovakia & Poland & $\begin{array}{l}\text { Czech } \\
\text { Republic }\end{array}$ & Hungary \\
\hline Seed financing & 3,170 & 1,671 & 712 & 3,117 \\
Start-up financing & 6,801 & 15,067 & 3,488 & 26,025
\end{tabular}


We can see that rescue and replacement capitals are not very popular in V4 countries. Only Poland provided replacement capital (nearly 23 million in 2015 and almost 10 million in 2016), none of the V4 countries invested in the rescue capital. On the other hand, the most popular investments are in management buy-outs, despite the fact that all countries except the Czech Republic had declined investments compared to 2015 and in addition, there is no management buy-out or investment in early development in 2016 in Slovakia. However, there is a positive development in investments in seed and start-up SMEs. Slovakia, in the volume of seed financing SMEs in 2016 outperformed Poland and also became the country with the largest investments in seed financing of SMEs in the CEE. Poland continued to focus on management buy-outs, but the expansion financing increased significantly $(42 \%)$ in the determined period. In Hungary, as well as in Poland, they experienced a decline in management buy-outs. The radical decreases in the number of management buy-outs in Slovakia and Hungary was caused by a lack of investor capital in such kind of investments. The same situation was with Czech PE funds, expansion investments were falling, whereas the seed and start-up investments increased. However, the Hungarian investments mainly differed in management byu-outs, which increased significantly compared to the previous year, up to more than 155 million euros.

\section{Global attractiveness index of the PE capital}

PE markets are most often focused on developing markets that attract investors to the opportunity of high economic growth. However, economic growth is not the only factor that reflects the attractiveness of the country for investment. The existence of a prosperous PE market and environment requires many socio-economic and institutional preconditions. Therefore, not every developing country is sufficiently mature within these assumptions. Too early entry into these countries could be a disadvantageous strategy. Therefore, the attractiveness index monitors the development of the assumptions and shows their improvements, allowing investors to get a better overview of foreign markets and to estimate the right time to invest.

The global attractiveness index summarizes the factors that form national PE markets into a single composite measurement. These factors from the sensitive PE markets were extensively studied in the literature. This literature was reviewed and the information gathered for the index was validated for several years, contributing to a better understanding of the driving force of international PE activity. The ability and reliability to select the factor correctly evolved and deepened at each new annual issue of the index. These factors are derived from the research and are divided into six subchapters (Groh et al., 2010). These subchapters illustrate the structure of the index, each representing one of the six key features of the country attractiveness for investors of PE capital: economic activity, depth of the capital market, taxation, investor protection and Corporate Governance, human and social environment, business culture and business opportunities. Table 3 summarizes the results of V4 countries when assessing the attractiveness of PE investors in 2017. 
Table 2: Assessment of attractiveness index in V4 countries

\begin{tabular}{|c|c|c|c|c|c|c|c|c|}
\hline \multirow[b]{2}{*}{ Key feature } & \multicolumn{2}{|l|}{ Slovakia } & \multicolumn{2}{|l|}{ Poland } & \multicolumn{2}{|c|}{ Czech Republic } & \multicolumn{2}{|l|}{ Hungary } \\
\hline & Ranking & Score & Ranking & Score & Ranking & Score & Ranking & Score \\
\hline Economic activity & 65. & 73,9 & 19. & 88,7 & 28. & 84,9 & 43. & 81,1 \\
\hline $\begin{array}{l}\text { Depth of the capital } \\
\text { market }\end{array}$ & 78. & 34,5 & 22. & 75,5 & 61. & 47,2 & 64. & 45,6 \\
\hline Taxation & 43. & 103,7 & 24. & 107,6 & 48. & 102,7 & 49. & 99,8 \\
\hline Investor protection a $\mathrm{CG}$ & 71. & 57,8 & 57. & 63,9 & 36. & 70,4 & 74. & 56,9 \\
\hline $\begin{array}{l}\text { Human \& social } \\
\text { environment }\end{array}$ & 69. & 44,2 & 34. & 61,7 & 18. & 72,1 & 48. & 52,3 \\
\hline $\begin{array}{l}\text { Business culture and } \\
\text { opportunities }\end{array}$ & 46. & 58,2 & 34. & 66,3 & 26. & 72,2 & 45. & 60,7 \\
\hline $\begin{array}{l}\text { VCPE country } \\
\text { attractiveness index }\end{array}$ & 71. & 50,4 & 26. & 72,3 & 33. & 65 & 52. & 56,2 \\
\hline
\end{tabular}

It is obvious that the attractiveness index is highest in the Poland, then the Czech Republic and Hungary and finally Slovakia, which was ranked 71th among 125 countries. The trend of Slovakia depicts that from 2013 to 2015, the position of the country improved until the year 2016 and then it was a significant decrease. The following year, Slovakia did not get worse, but it did not even improve and held the 71st place. Concerning the comparison with the average of CEE countries, Slovakia averaged economic activity, taxation, business opportunities and investor protection. The assessment of the depth of the capital market and human and social environments are below the average results. Compared to 2013, Slovakia dropped 6 places and is rated unattractive for investors (Figure 3).

Figure 3: Attractiveness index and spider plot of key features for Slovakia
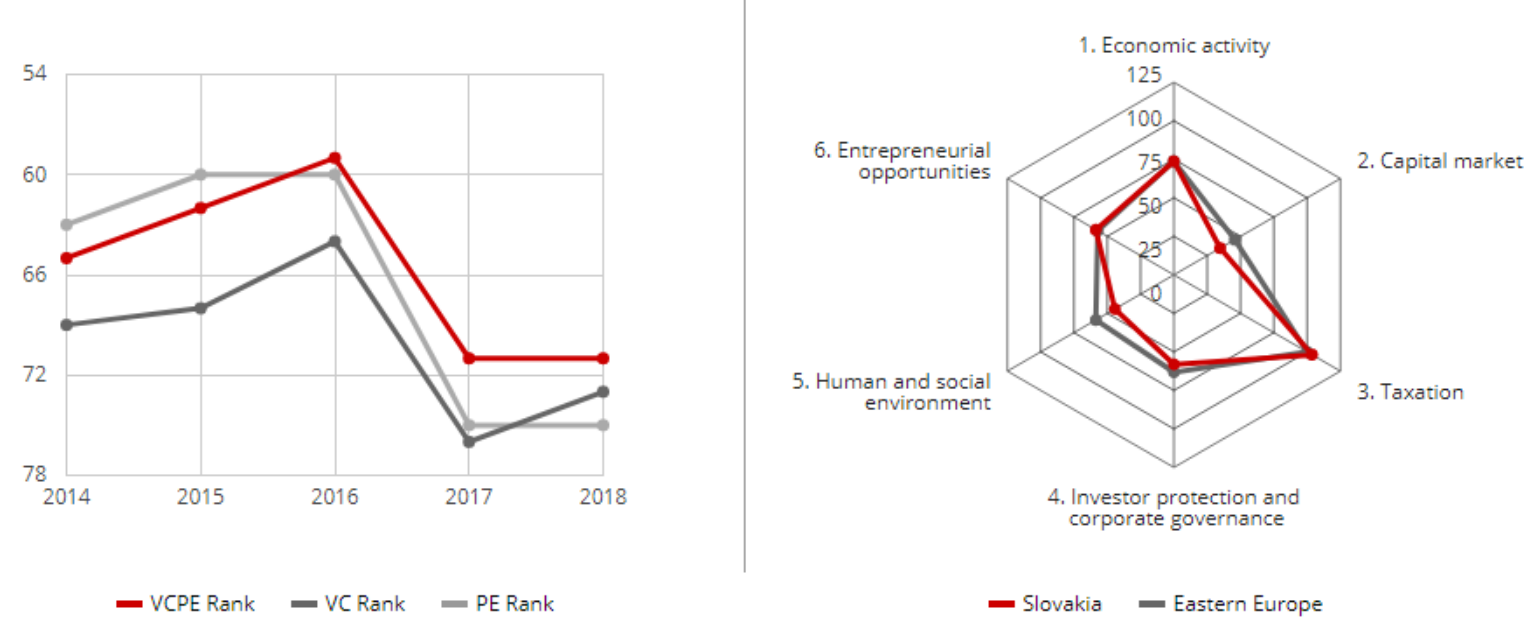

Source: http://blog.iese.edu/vcpeindex/

Hungary ranks among the average countries; the trend shows that the fall that lasted from 2013 was replaced by slight increase and the situation with PE capital improved. When considering the feature in spider plot, the area of human and social environment and investor protection are below the CEE average but, on the other hand, in the area of economic activity it exceeds this average. In other areas, the results achieved overlap with the average of the CEE (Table 4). Hungary also fell by six places compared to 2013, the country lost its attractiveness and investors should be cautious when considering their investments. 
Figure 4: Attractiveness index and spider plot of key features for Hungary
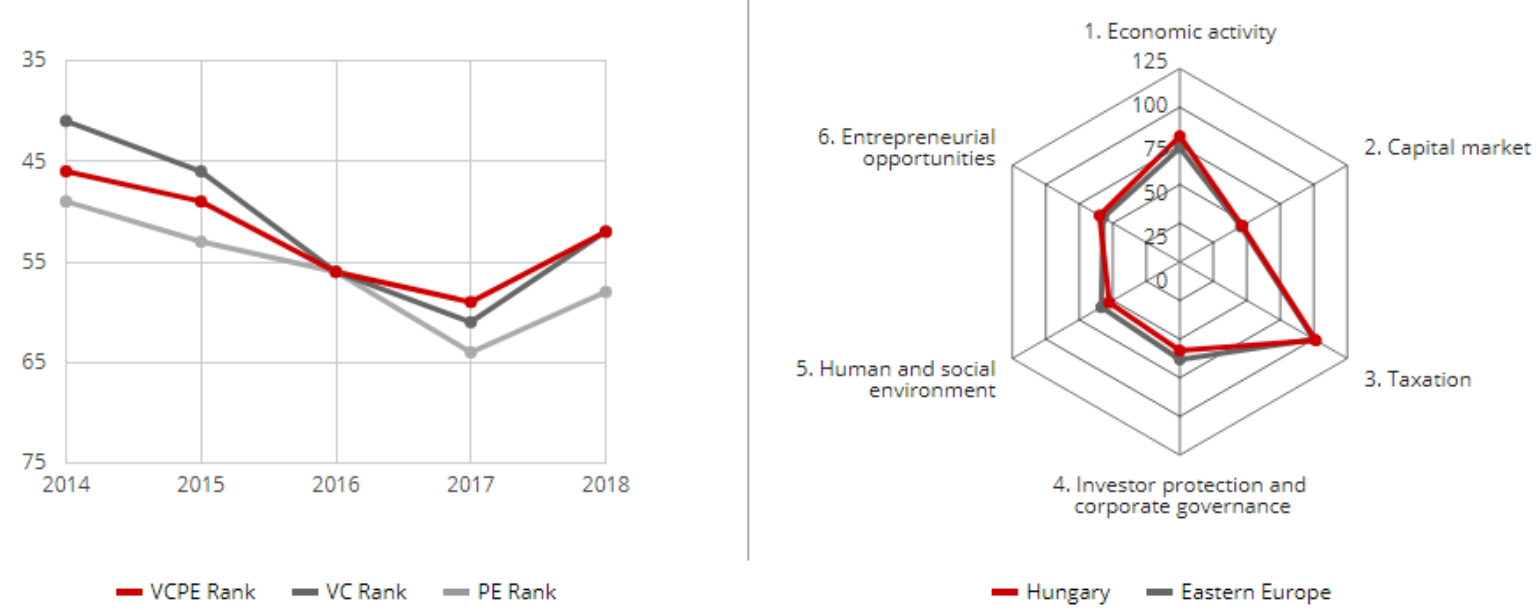

Source: http://blog.iese.edu/vcpeindex/

The Czech market is growing year by year, reflecting the attractiveness for investors. The areas that need to be improved to belong to the group of the most attractive countries of the world are the depth of the capital market and taxation. In other areas, the average of CEE countries was exceeded, particularly in the area of enterprise opportunities and the human and social environment (Figure 5). The positive development trend over the last four years gave the country an index rating of a high attractive country with investment recommendation.

Figure 5: Attractiveness index and spider plot of key features for the Czech Republic
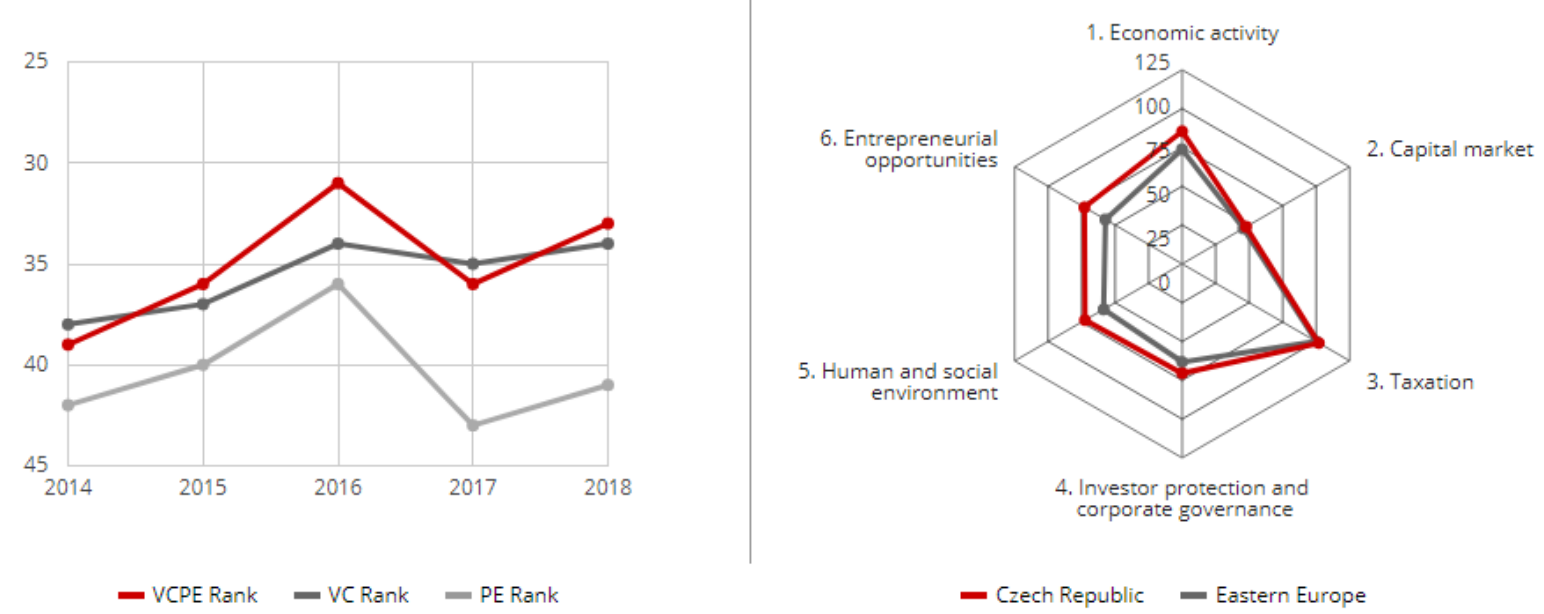

Source: http://blog.iese.edu/vcpeindex/

Poland had the best position among the CEE countries. In the area of human and social environment and investor protection, Poland is around the average of the CEE region. In other areas, the country is above this boundary. Due to the size and strength of the Polish PE market, it is considerably higher than the CEE in terms of economic activity and the depth of the capital market. In the last four years, Poland is the same group of countries as the Czech Republic, which is an attractive country for investor; it is advised to invest in it or to increase the existing investments. 
Figure 6: Attractiveness index and spider plot of key features for Poland
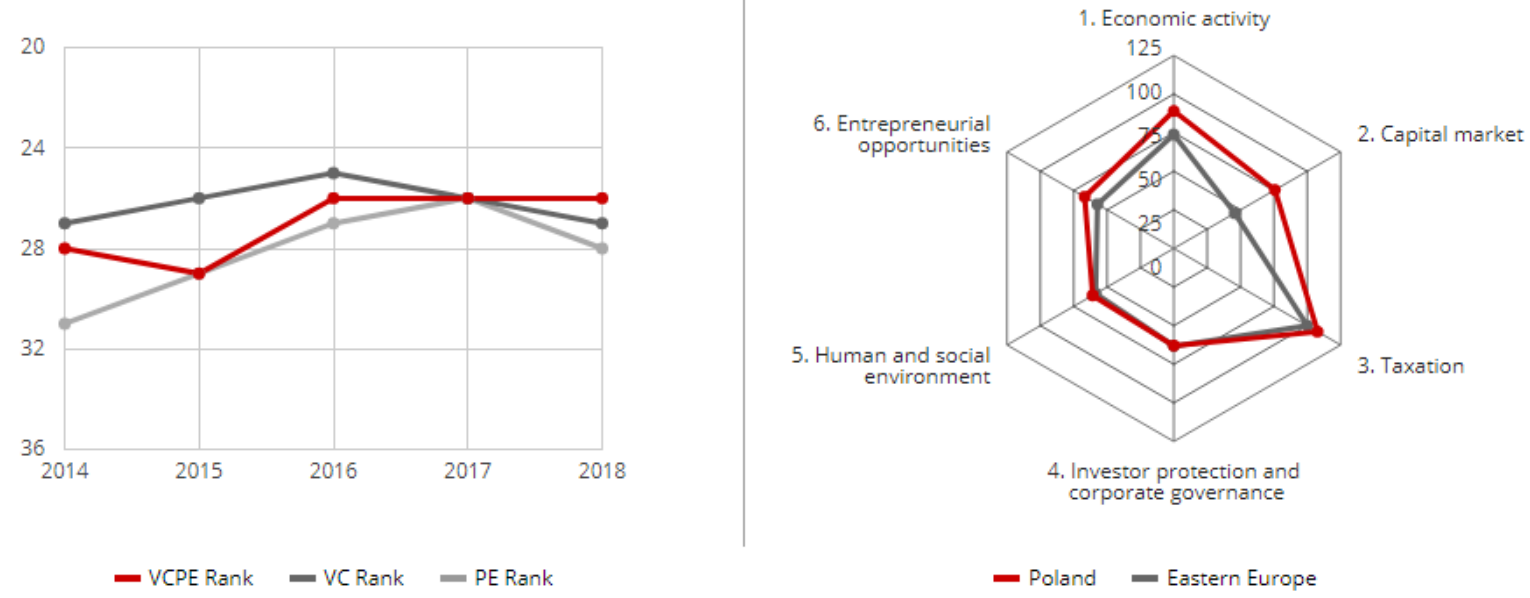

Source: http://blog.iese.edu/vcpeindex/

\section{Correlation and regression analyses}

We need to determine dependent and independent variables. Dependent variable is the resulting score of the country attractiveness index (VCPE) and factors of the attractiveness index are considered independent variables, i.e. business culture and business opportunities, taxation, economic activity, human and social environment, capital market depth and investor Protection and Corporate Governance. We determine a value of 0.01 for the significance level $(\alpha)$ in regression analysis, which means that we admit $1 \%$ error in the hypothesis testing. When testing the regression analysis, we compare the significance level with the p-value. If the pvalue is lower than the significance level, we reject the null hypothesis that the regression model is statistically insignificant and accept the alternative hypothesis, that the regression is statistically significant. And, vice versa, if the p-value is greater than the significance level, we do not reject the null hypothesis that the regression is statistically insignificant.

First, we use graphical analysis to check the linear dependence of the VCPE index of attractiveness, to each factor of attractiveness, and we express it in a point graph (Figure 7). In the graphical analysis, we found that all factors are linearly dependent on the country attractiveness index. Obviously, there are no significant outsiders. In the graphs at the top right we can see the coefficients of determination, which determines the quality of the regression model. Thus, it explains how many per cents of the variable variability (VCPE attractiveness index) is captured by the given line. The closer to the value of $100 \%$, the better the linear model. It is clear that the highest value has the factor of the capital market depth, which explains $91.8 \%$ of the dependent variables variability. Following is the factor of business culture and business opportunities, describing $88.7 \%$ of the variability. Moderate linear dependence is typical of other factor: investor protection and corporate governance and the human and social environment explain the variability at $69.6 \%$ and $63.7 \%$, respectively. The factors that least describe the attractiveness index are the factors of economic activity $(46.6 \%)$ and taxation (33.6 $\%)$. 
Figure 7: Graphical analysis of linear dependence
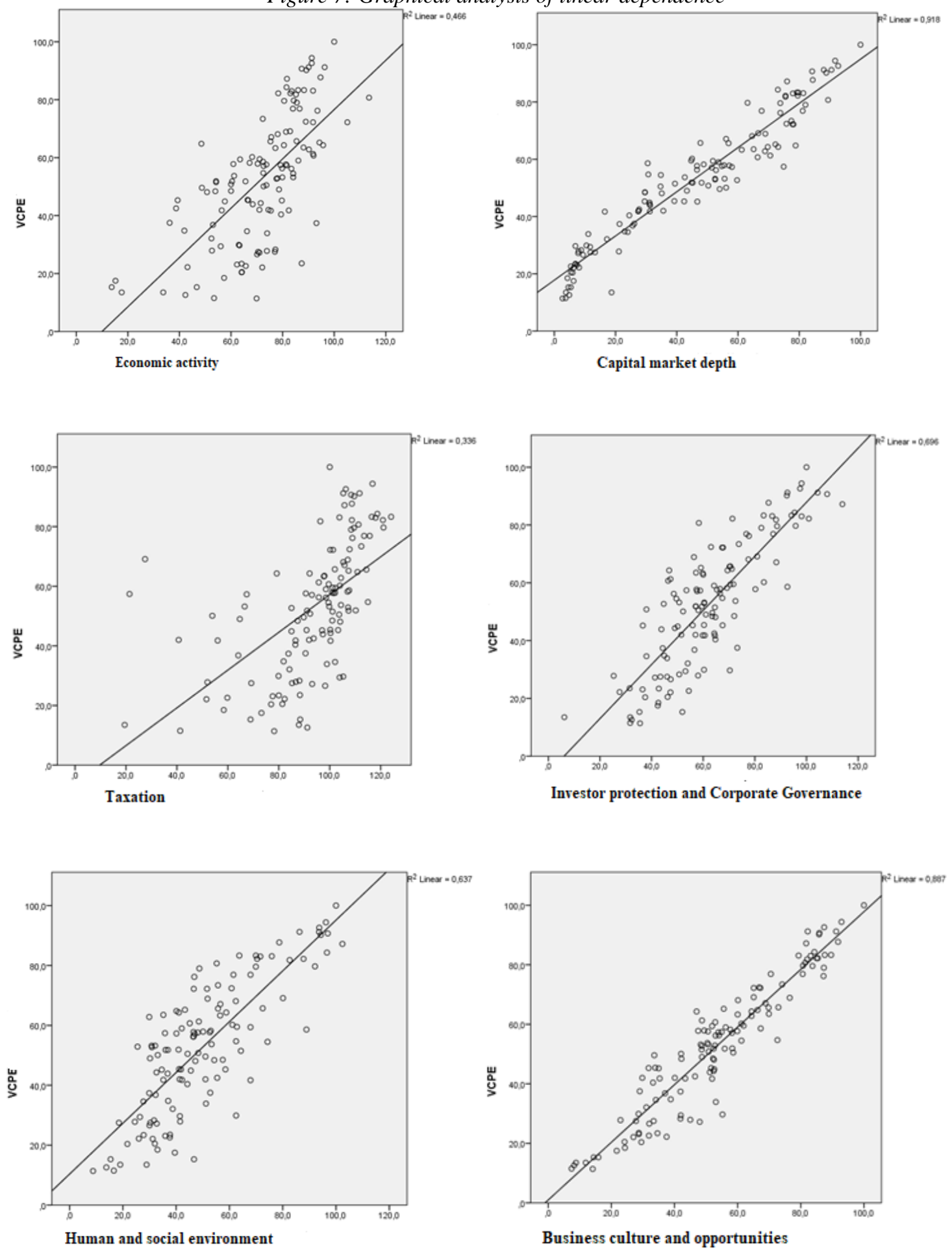

Source: Author's compilation

Subsequently, we process the data in a correlation analysis to obtain the Pearson correlation coefficient, which determines the correlation strength, as well as the statistical significance of this correlation (Table 4). 
Table 4: Correlation analysis

\begin{tabular}{llllllll}
\hline Factor & Coefficient & $\begin{array}{l}\text { Business } \\
\text { culture \& } \\
\text { opportunities }\end{array}$ & $\begin{array}{l}\text { Human \& } \\
\text { social } \\
\text { environment }\end{array}$ & $\begin{array}{l}\text { Investor } \\
\text { protection, } \\
\text { CG }\end{array}$ & Taxation & $\begin{array}{l}\text { Capital } \\
\text { market } \\
\text { depth }\end{array}$ & $\begin{array}{l}\text { Econ. } \\
\text { activity }\end{array}$ \\
\hline VCPE & Pearson & 0.942 & 0.798 & 0.834 & 0.580 & 0.958 & 0.682 \\
& p-value & 0.000 & 0.000 & 0.000 & 0.000 & 0.000 & 0.000 \\
\hline
\end{tabular}

Source: Author's compilation

In Table 4, we see that the statistical significance (p-value) of each factor is lower than the significance level, which means that all factors are significant for the correlation. The resulting table shows that the highest correlation to the country attractiveness index has the factor of business culture and business opportunities, and the depth of the capital market. Both factors have reached a high value of strong dependence. The factor of business culture and business opportunities reached 0.942 and the capital market depth was even slightly higher, 0.958 . On the contrary, the least impact on the creation of the country attractiveness index has the factor of taxation.

In the next step, the author provides the regression analysis. Table 5 summarizes the results of the regression analysis. It can be claimed, that the linear regression model is strongly linearly dependent which is represented by the value of the coefficient of determination (0.994). Thus, the model explains $99.4 \%$ of the dependent variable variability.

Table 3: Summary of the regression model

\begin{tabular}{lllll}
\hline Model & $\mathrm{R}$ & R square & $\begin{array}{l}\text { Adjusted R } \\
\text { square }\end{array}$ & $\begin{array}{l}\text { Std. Error of the } \\
\text { estimate }\end{array}$ \\
\hline 1 & 0.997 & 0.994 & 0.994 & 1.7132 \\
\hline
\end{tabular}

Source: Author's compilation

Table 6 summarizes the results of the ANOVA test, providing the information about the model significance. The p-value (Sig.) is followed, and as it is lower than the significance level $(0.000<0.01)$, the model was formed properly and is statistically significant.

Table 6: ANOVA

\begin{tabular}{lllllll}
\hline Model & & Sum of squares & df & $\begin{array}{l}\text { Mean } \\
\text { square }\end{array}$ & F & Sig. \\
\hline 1 & Regression & $60,052.751$ & 6 & $10,008.792$ & $3,409.972$ & 0.000 \\
& Residual & 346.348 & 118 & 2.935 & & \\
& Total & $60,399.099$ & 124 & & & \\
\hline
\end{tabular}

Source: Author's compilation

In the last regression analysis table, Table 7, we find the value of the locating constant as well as the regression coefficient values and their standard deviations. Equally important is the last column of the table, where we find the statistical significance of these coefficients. The pvalues of all independent variables are below the level of significance which means that all variables are considered significant and can be used the regression model of the prediction of the country attractiveness in the area of PE capital.

Table 7: Regression coefficients

\begin{tabular}{llllll}
\hline \multirow{2}{*}{ Model } & \multicolumn{2}{l}{$\begin{array}{l}\text { Unstandardized } \\
\text { Coefficients }\end{array}$} & $\begin{array}{l}\text { Standardized } \\
\text { coefficient }\end{array}$ & $\mathrm{t}$ & Sig. \\
\cline { 2 - 6 } & $\mathrm{B}$ & $\begin{array}{l}\text { Std. } \\
\text { Error }\end{array}$ & Beta & & \\
\hline $1 \quad$ Constant & -3.416 & 1.042 & & -3.278 & 0.001
\end{tabular}




\begin{tabular}{llllll} 
Economic activity & 0.076 & 0.012 & 0.061 & 6.049 & 0.000 \\
Capital market depth & 0.451 & 0.011 & 0.560 & 39.926 & 0.000 \\
Taxation & 0.046 & 0.010 & 0.042 & 4.450 & 0.000 \\
Investor protection, CG & 0.115 & 0.017 & 0.103 & 6.615 & 0.000 \\
Social \& Human Environment & 0.150 & 0.015 & 0.164 & 9.987 & 0.000 \\
Business culture \& opportunities & 0.212 & 0.020 & 0.206 & 10.368 & 0.000 \\
\hline
\end{tabular}

Source: Author's compilation

The regression model may be written as:

$$
y=-3,416+0,076 * x_{1}+0,451 * x_{2}+0,046 * x_{3}+0,115 * x_{4}+0,150 * x_{5}+0,212 * x_{6}
$$

The function of the regression model is then used to determine the future attractiveness of the country in the area of the PE capital. We compare the resulting score estimated by the regression model with the predicted score according to the PE annual report of the global attractiveness index. We will also evaluate the resulting score in relation to the score that the country achieved in the Global Competitiveness Index for 2017/2018. The Global Competitiveness Index assesses the ability of countries to achieve sustainable economic growth in the medium term horizon, thereby ensuring a high level of prosperity for the country citizens. It integrates macroeconomic and microeconomic business aspects of competitiveness and links them into one index. It analyses the level of public institutions, infrastructure, macroeconomic stability, population health and basic education, higher education and training, efficiency of the goods market, labour market efficiency, financial market maturity, technological readiness, market size, business process excellence and innovation level. The index is published annually by the World Economic Forum and evaluates 144 countries. The resulting country score can range from 1 , which is minimal competitiveness to 7 , which represents maximum competitiveness. The final comparison of all mentioned methods is depicted in the Table 8 .

Table 8: Comparison of the regression model with other global indices

\begin{tabular}{llllll}
\hline \multicolumn{1}{l}{ Country } & & Slovakia & $\begin{array}{l}\text { Czech } \\
\text { Republic }\end{array}$ & Hungary & Poland \\
\hline Regression model & Abs. & 48.3 & 63.7 & 55.6 & 73 \\
\multirow{2}{*}{ VPCE index } & Rel. & $48.3 \%$ & $63.7 \%$ & $55.6 \%$ & $73 \%$ \\
& Abs. & 50.5 & 65.7 & 57.7 & 72.4 \\
Competitiveness index & Rel. & $50.5 \%$ & $65.7 \%$ & $57.7 \%$ & $72.4 \%$ \\
& Abs. & 4.33 & 4.77 & 4.33 & 4.59 \\
\% difference between regression model and VPCE & Rel. & $61.9 \%$ & $68.1 \%$ & $61.9 \%$ & $65.6 \%$ \\
$\%$ difference between regression model and comp. & $-2.2 \%$ & $-2.0 \%$ & $-2.1 \%$ & $0.6 \%$ \\
index & & & & & \\
\hline
\end{tabular}

Source: Author's compilation

To sum up, the results of the VCPE index measured by the formed regression model differ only slightly from the values estimated by the country attractiveness index (the highest difference is of $2.2 \%$ ), which confirms the formation of model with high prediction ability. However, there are differences between indices of attractiveness and competitiveness, which are larger for some countries, e.g. for Slovakia, where the difference of the VCPE index from the regression model was $13.6 \%$ lower than the competitiveness index. For the remaining countries, the difference was not as remarkable and did not exceed 10\%. In all countries except Poland, the ratio between attractiveness and competitiveness was lower in negative aspect to the country attractiveness. However, Poland achieved a high position among the world selection of countries in the attractiveness index, but it did not stand well in the Competitiveness Index. 


\section{Discussion}

Private equity, since its first explanation, has been a subject of many studies and object of interest of many experts. Maula et al. (2005) concluded that private equity is the reason of the extraordinary ability of the American economy to transform innovative ideas from university and research laboratories into high growth companies. In the United States, and also in the UK, after the Second World War, private equity was perceived as one of the means of economic recovery and as a defensive tool before the economic recession (Lerner et al., 2012). Both governments started to be engaged in the support of private equity funds. On the contrary, the role of private equity capital in Central and Eastern Europe was different from that played in developed market economies. Private equity only helped to develop globally as a very specific financial instrument used in industries. The immaturity of the private equity market in the CEE was declared by a small number of PE investors focusing on companies in high tech sectors, stated by Kislingerova \& Novy (2005). The development of the PE markets in the CEE region was described by other authors, e.g. Filatotchev et al. (1996), and Karsai et al. (1999) who followed the investment decisions of regional investors compared to those operating on global markets. They also analysed the characteristics of CEE markets and their main barriers. It was proved that although the markets have some common features in the area of investment, the greater risk of the region lies in the understanding of investment trends and the fact that market development requires higher quality projects and wider possibility of disinvestment. Gregorova (2007) in her review claims that only a small number of companies in the region get capital in the early stages of their development, which may explain the poor quality of the projects and the lack of infrastructure for the specified transactions. Another barrier is the small number of informal investors, according to Szerb et al. (2007). Groh \& Liechtenstein (2009) studied the attractiveness of CEE countries for PE investors. Their study is based on questionnaires addressed to institutional investors. They tried to find out the importance of the investment criteria of the development markets, leading to a ranking of the attractiveness of developing countries for PE investors. The study showed that CEE countries are less attractive than the EU-15 average. In this region, investors are attracted by low corporate tax rates, but discouraged by their low liquidity on national capital markets.

The situation in the CEE region, especially in the countries of the Visegrad group, in the area of PE capital was the main aim of the research of the paper. The private equity investments in the V4 countries reached more than $60 \%$ share on the PE investments in Central and Eastern Europe in 2017. However, Slovakia has the smallest share of V4 countries. It was founded, that Slovakia is behind in the volume of PE investments mainly due to a lack of investment in management buy-outs. However, the most important aim was to identify the influence factors of the PE capital, which was done using the results of the correlation and regression analysis in which we processed data from the country attractiveness index in the area of private equity. Based on the results, two most influential factors affecting the country attractiveness index are the depth of the capital market and business culture and business opportunities. The formed regression model help predict the attractiveness of the country for PE investors and the comparative analysis proved perfect prediction ability of the regression model.

\section{References}

Achleitner, A.K., Kloeckner, O. (2005). Employment Contribution of Private Equity and Venture Capital in Europe. Výskumná správa. Mníchov, Germany: Technische Universität München.

Burdel, S. (2009). Private Equity Secondaries: Opening the Liquidity Tap. Thunderbird International Business Review, 51(6), 533-537. 
Bygrave, W.D. \& Timmons, J.A. (1986). Venture Capital's Role in Financing Innovation for Economic Growth. Journal of Business Venturing, 1(2), 161-176.

Diaconu, M. (2012). Characteristics and Drivers of Venture Capital Investments Activity in Romania. Theoretical and Applied Economics, 19(7), 93-114.

Dvorak, I. \& Prochazka, P. (1998). Rizikový a Rozvojový Kapitál. Venture Capital. Praha, Česká republika: Management Press.

EVCA (2007). Central and Eastern Europe Statistics 2006. EVCA Special Paper. [online]. [cited 11. August 2017]. Available on the internet: <https://bit.ly/2HSaNb6>

EVCA (2017). 2016 European Private Equity Activity [online]. 2017. [cited 11. August 2017]. Available on the internet: <https://bit.ly/2uJjEEn>

Filatotchev, I. et al. (1996). Corporate Restructuring in Russian Privatizations: Implications for US Investors. California Management Review, 37(2), 87- 100.

Fryges, H. \& Wright, M. (2014). The Origin of Spin-offs: A Typology of Corporate and Academic Spin-Offs. Small Business Economics, 43(2), 245-259.

Gervasoni, A. \& Sattin, F.L. (2006). Private Equity e Venture Capital: Mauale di Investimento Nel Capitale Rischio. 3. Vydanie, Miláno, Italy: Edizioni Angelo Guerinin e Associati.

Gregorova, L. (2007). The Knowledge-Based Economy in Central and Eastern Europe (Countries and Industries in a Process of Change). Politická ekonomie, 55(2), 278-281.

Groh, A.P. \& Liechtenstein, H. (2009). How Attractive is Central Eastern Europe for Risk Capital Investors? Journal of International Money and Finance, 27(4), 625-647.

Isaksson, A. et al. (2004). Institutional Theory and Contracting in Venture Capital: The Swedish Experience. Venture Capital, 6(1), 47-71.

Kaplan, S.N. \& Stromberg. P. (2009). Leveraged Buy-Outs and Private Equity. Journal of Economics Perspectives, 23(1), 121-146.

Karsai, J. et al. (1999). Transition and Active Investors: Venture Capital in Hungary, Poland and Slovakia. Postcommunist Economies, 9(1), 27-46.

Kislingerova, E. \& Novy, I. (2005). Chování Podniku v Globalizujícím se Prostředí. Praha, Česká republika: C. H. Beck.

Kortum, S. \& Lerner, J. (2000). Assessing the Contribution of Venture Capital to Innovation. RAND Journal of Economics, 31(4), 674-692.

Leeds, R. (2015). Private Equity Investing in Emerging Markets. Basingstoke, Great Britain: Palgrave Macmillan.

Lerner, J., Leamon, A. \& Hardymon, F. (2012). Venture Capital, Private Equity, and the Financing of Entrepreneurship. Hoboken, New Jersey: Wiley.

Link, A.N., Ruhm, C.J. \& Siegel D.S. (2013). Private Equity and the Innovation Strategies of Entrepreneurial Firms: Empirical Evidence from the Small Business Innovation Research Program. Managerial and Decision Economics, 35(2), 103-113.

Mason, C.M. \& Harrison, R.T. (1999). Venture Capital: Rationale, Aims and Scope. Venture Capital, 1(1), 1-46.

Maula, M., Autio, E. \& MURRAY, G. (2005). Corporate Venture Capitalists and Independent Venture Capitalists: What Do They Know, Who Do They Know and Should Entrepreneurs Care? Corporate Entrepreneurship and Venturing, 10(1), 101-126.

Nyvltova, R. \& Reznakova, M. 2007. Mezinárodni Kapitálové Trhy Jako Zdroj Financování. Praha: Grada Publishing.

Sharp, W., Alexander, G.J. \& Bailey, J.V. (1994). Investments. Englewood Cliffs: Prentice Hall.

Stowell, D.P. (2018). Investment Banks, Hedge Funds, and Private Equity. London, Great Britain: Academic Press Ltd.

Szerb, L., Rappai, G., Makra, Z. \& Terjesen, S. (2007). Informal Investment in Transition Economies: Individual Characteristics and Clusters. Small Business Economics, 28(2), 257-271.

Veber, J. (2008). Podnikání Malé a Střední Firmy. Praha, Česká republika: Grada Publishing, a. s. 